\title{
ISLAMISASI DI KAWASAN LAUT SULAWESI PADA ABAD KE-19
}

\section{ISLAMIZATION IN SULAWESI SEA AREA AT $19^{\text {th }}$ CENTURY}

\author{
Muhammad Nur Ichsan Azis \\ Balai Pelestarian Nilai Budaya Sulawesi Utara \\ J1. Katamso, Bumi Beringin, Lingkungan V, Wenang, Manado, Sulawesi Utara \\ E-mail: icchankazis18@gmail.com
}

DOI: $10.36424 / j p s b . v 5 i 1.14$

Naskah Diterima:22 Januari 2019 Naskah Direvisi:28 Aprili 2019 Naskah Disetujui: 01 Juni 2019

\begin{abstract}
Abstrak
Islamisasi yang terjadi di Nusantara pada abad ke-19 tidak terlepas dari peran dan pengaruh para pedagang sekaligus ulama dari Timur Tengah yang membawa ajaran Islam. Proses Islamisasi dan konversi agama membutuhkan waktu dan proses panjang, hingga sampai diterima oleh masyarakat setempat. Penerimaan ajaran Islam dilakukan melalui beberapa saluran, terutama dalam jaringan perdagangan. Kawasan Laut Sulawesi, sebagai entrepot, merupakan salah satu jalur Islamisasi karena perkembangan perdagangan rempah-rempah di Maluku sebagai wilayah penghasil rempahrempah.Tulisan ini bertujuan mengungkap proses Islamisasi di sekitar Kawasan Laut Sulawesi pada abad XIX.Tulisan ini merupakan tulisan sejarah, dengan menggunakan metode sejarah; heuristik, kritik, interpretasi, dan historiografi yang bersifat analisiskualitatif dan mampu menunjukkan satu rangkaian proses Islamisasi yang terjadi di Nusantara sekitar abad XIX. Hasil kajian ini menunjukkan bahwa pengaruh Islam diawali dari proses perdagangan, di kawasan Laut Sulawesi, bagi pedagang yang menghubungkan ke Maluku sebagai satu pola Islamisasi, sehingga di masa berikutnya komunitas Muslim mampu menciptakan Moslemen clave di Semenanjung Laut Sulawesi.
\end{abstract}

Kata Kunci: Islamisasi, Pedagang, Semenanjung Laut Sulawesi

\begin{abstract}
Islamization in the archipelago in the $19^{\text {th }}$ Was strongly influenced by the merachant role and scholars from Arab Peninsulaand Middle East who brought teachings. The process of Islamization and religious conversion take a long time and process until it was accepted by the local community. The acceptance of Islamic teachings was through several especially in the trade network. The Celebes Sea, as an entrepot, is one of the paths of Islamization caused by spices trading on Maluku. This paper aimed at describing the process of Islamization around Celebes Sea at $19^{\text {th }}$. This paper historical writing, using historical methods; heuristic, critic, interpretation, and historiography to indicate Islamization processes at $19^{\text {th }}$. The results of this study indicates that islamic influence begins with the trading process, in the Celebes Sea, merchants connecting, to Maluku as a pattern of Islamization, so that in the following period the Muslim community was able to create a Muslim enclave on the Celebes Peninsula.

Keywords: Islamization, Trade, Celebes Peninsula
\end{abstract}




\section{PENDAHULUAN}

Sejarah mencatatkan bahwa proses persebaran ajaran Islam di Nusantara tidak lepas dari peran pedagang yang datang dari daratan Arab, India, hingga Cina. Islam di Nusantara mengalami persebaran yang signifikan sejak abad ke-13 hingga abad ke-16. Salah satu ciri khasnya adalah terciptanya masyarakat muslim Nusantara, meskipun di satu sisi masih mengalami perdebatan panjang. Walau demikian, para sejarawan sepakat bahwa ajaran Islam tidak lepas dari para pedagang, kaum sufi dan ulama, serta pelalku tarekat (Karim, 2014: 326). Persebaran ajaran Islam dihubungkan dengan ekspansi hingga penaklukan wilayah yang di dalamnya terdapat aktifitas niaga dan dakwah (Hamka, 1963: 265; Hasjmy, 1981: 7; van Leur, 1960: 91). Tetapi para orientalis sepakat bahwa pengaruh Islam di Nusantara diperkirakan baru terjadi sejak abad ke-13 (Tignor, 2007: 116-117; Jhons, 1995: 175).Walaupun demikian, dapat ditarik kesimpulan bahwa Islam yang masuk ke Nusantara mengalami akselerasi persebaran sejak abad ke-12 sampai ke-16 (Azra, 1999: 30-31), melalui beberapa saluran, terutama perdagangan, pendidikan, dan pernikahan yang dapat dilacak jejaringnya.

Tema pokok yang mudah untuk melihat jejaring tersebut adalah melalui jalur perdagangan dan kekuasaan. Ricklefs (2008: 23) menuliskan bahwa ajaran pengaruh Islam bukti arkeologis mengenai berdirinya Kesultanan Perlak di Semenanjung Malaka, dan Kesultanan Aceh. Kekuatan ekonomi-politik mampu menarik perhatian para penyebar Islam untuk memperkuat keberadaan mereka. Sebagaimana Marco Polo menyebutkan bahwa telah berdiri sebuah emporium dagang Muslim di bawah pengaruh Kesultanan Perlak pada abad ke-13 M, sehingga terlihat adanya kontak dagang dan politik antara penduduk pribumi dengan penyebar ajaran Islam, khususnya di Nusantara (Ricklefs, 2008: 23-24). Untuk memperkuat kesimpulan tersebut, maka kontak tersebut ditandai dengan penggunaan madzhab dalam dunia pemikiran Islam, syafi'iyah,yang dipraktekkan oleh penduduk Perlak dan masyarakat Nusantara, yang kemudian semakin tersebat luas ke beberapa wilayah, termasuk pesisir Sumatera, Jawa, Kalimantan, Sulawesi, dan Maluku. 
Persebaran ajaran Islam juga terjadi di kawasan Laut Sulawesi. Pada abad ke-19, kawasan Laut Sulawesi merupakan wilayah yang ramai dilalui para pedagang, termasuk pedagang Islam, sehingga peran ekonomi-politik dapat ditelusuri melalui peran dan aktifitas niaga. Letak geografis Laut Sulawesi berada pada jalur dagang di kawasan Timur Nusantara dimana para pedagang harus melewati Selat Makassar menuju Laut Sulawesi hingga ke Selat Maluku. Kawasan ini tidak lepas dari jejaring rempah-rempah yang ada di Maluku. Ternate disebutkan sebagai daerah yang merasakan pengaruh ajaran Islam, hingga mampu menyebarkan ajaran Islam (Taulu, 1977: 3). Di sisi lain, perebutan rempahrempah berakibat pada kondisi geo-politik dan persebaran ajaran Islam yang terjadi di daratan Sulawesi (2009: 68-71).

Terdapat tiga kekuatan politik Islam yang berpengaruh di kawasan Laut Sulawesi. Kekuatan tersebut adalah; Kesultanan Makassar, Kesultanan Ternate, dan Kesultanan Sulu yang identik dengan persebaran ajaran Islam di daratan Sulawesi yang terutama pada abad ke-17. Kesultanan Makassar, Kesultanan Ternate, dan Kesultanan Sulu mampu melakukan ekspansi ke kawasan Semenanjung Laut Sulawesi. Terjadi perebutan pengaruh antara, Kesultanan Makassar, Kesultanan Ternate, dan Kesultanan Sulu di Laut Sulawesi, sebelum pengaruh Eropa menguat (Sewang, 2005: 76). Ketiga Kesultanan ini berperan dalam perpindahan komoditas dagang yang terlihat secara sepintas ketika perdagangan budak mencapai puncaknya pada abad ke-19 (Warren, 1979: 226), dimana budak diekspor dari Sulu yang berdampak pada jalur perdagangan dan jejaring islamisasi hingga ke wilayah pedalaman.

Beberapa kawasan pulau kecil juga berpengaruh dalam mendukung perkembangan Islam di Semenanjung Laut Sulawesi. Deretan pulau-pulau kecil dikatakan sebagai jembatan alami dalam dunia perdagangan di dunia yang menghubungkan Cina dan Nusantara di masa lalu. Kawasan dikenal seabgai jalur dagang yang kemudian berdampak pada munculnya kekuatan ekonomi-politik untuk menguasai daerah ini. Pengaruh tersebut dapat ditelusuri dari jejaring perdagangan, dan politik yang membentuk identitias pada awal dekade 2000-an di Semenanjung Laut Sulawesi (Sis, 2002: 38). 
Posisi Laut Sulawesi yang strategis membentuk sebuah jejaring dan jalur perdagangan maritim antara Sulawesi dan Maluku. Di bagian Selatan Pulau Sulawesi, terdapat Kesultanan Makassar mengalami perkembangan yang pesat setelah membuka jalur perdagangan internasional. Makassar, sebagai salah satu entrepot, di kawasan Semenanjung Laut Sulawesi sebelum memasuki Laut Maluku. Lebih lanjut, Kesultanan Makassar memiliki wilayah taklukkan hingga daratan Manado (Mattulada, 2011: 87), sehingga para pedagang muslim dengan leluasa melakukan perjalanan dari bandar Makassar menuju Maluku.

Puncaknya ketika kawasan ini menjadi wilayah persinggahan karena cuaca dan angin musim, sehingga beberapa bandar di sepanjang garis pantai antara Selat Makassar dan Laut Sulawesi dapat di antaranya: Tontoli (Toli-Toli), Gorontalo, Bolaang dan Mongondow, Belang, Manado, Kema, dan Banggai (Moelsbergen, 1928: 8-9). Sedangkan pada kawasan lain terdapat pulau-pulau kecil, Sangihe dan Talaud, sebgai penghubung alami dan entrepot, bagi para pedagang yang menyusuri Selat Luzon bagi para pedagang Cina, dan Sulu kemudian ke Maluku (Ulaen, 2016: 38-40).

Berawal dari perebutan hegemoni antara Makassar dan Ternate di Kawasan Laut Sulawesi yang berusaha menerapkan hegemoni untuk memperkuat posisi mereka dimana keduanya saling memasukkan kawasan Laut Sulawesi sebagai vasal. Namun ketika pengaruh pedagang Eropa, terutama Belanda, terlibat dalam konflik yang terjadi Makassar dan Ternate di Kawasan Laut Sulawesi, berhasil dimabil alih oleh Belanda (Lapian, 2009: 70). Selain perebutan hegemoni antara Makassar dan Ternate, terdapat juga Kesultanan Sulu yang mencoba menanamkan pengaruhnya di daerah utara, terutama di Mindanao, Manguindao, Sangihe-Talaud, dan beberapa wilayah di daerah pesisir utara Laut Sulawesi. Proses ini menunjukkan adanya dua kubu yang berusaha menanamkan pengaruh di Semenanjung Laut Sulawesi yakni penguasa sekitar dan peran kolonisasi Eropa. Posisi ini kemudian membuat Semenanjung Laut Sulawesi dan beberapa daerah daratannya menjadi kawasan"primadona" bagi para pedagang yang menuju Malaku terutama pada abad ke-19 M. 
Usaha Belanda cukup terlihat di kawasan tersebut untuk memonopoli perdagangan rempah-rempah di jalur Maluku dan semenanjung Laut Sulawesi. Namun pihak Belanda juga melupakan peran dari para pedagang Muslim yang sudah lama menjalin hubungan dengan penduduk pribumi, sehingga terlihat di beberapa kesempatan usaha Islamisasi masih terjadi di kawasan tersebut yang luput dari perhatian Belanda. Di sisi lian, Belanda juga menerapkan misi zending yang ditujukan untuk membentuk koloni, terutama dalam menjalankan praktek keagamaan. Dan hal tersebut terbukti di beberapa daerah koloni Belanda yang berhasil oleh misi zending Belanda, termasuk Manado dan beberapa pulau kecil di Semenanjung Laut Sulawesi. Oleh karena itu, menarik untuk melakuka kajian dan penulisan mengenai kawasan Semenanjung Laut Sulawesi yang didukung oleh aktifitas masyarakat, terutama perdagangan dan hubungan dengan pendatang. Misi keagamaan yang mengalami perjumpaan di kawasan Semenanjung Laut Sulawesi terlihat sebagai satu misi yang tidak mendapatkan perhatian cukup dari pemerintah Belanda di daerah koloninya, sebab aktifitas tersebut tidak berdampak besar pada aktifitas politik dan perdagangan Belanda di abad ke-19. Kawasan Semenanjung Laut Sulawesi sebagai wilayah triangle strategis: Laut Sulawesi, Selat Makassar, dan Selat Maluku, bukan tidak mungkin sudah diduduki oleh para pedagang Muslim dari Arab, Cina, India, dan Persia terlebih dahulu, sehingga melihat hal tersebut, penulis kemudian mengajukan beberapa pertanyaan mengenai proses Islamisasi yang terjadi; pertama, bagaimana pengaruh para pedagang muslim di kawasan Semenanjung Laut Sulawesi; kedua, Seperti apa dan sejauh mana proses Islamisasi Kesultanan Makassar, Ternate dan Sulu dalam memafaatkan jalur perdagangan di kawasan tersebut; ketiga, seperti apa dampak dari proses Islamisasi yang terjadi di kawasan Semenanjung Laut Sulawesi. Olehnya itu, penulis berusaha menjawab pertanyaan tersebut dalam tulisan ini, sebuah proses Islamisasi yang begitu kompleks karena perkembangan Islam yang terjadi tidak terlepas dari pengaruh pedagang dan perdagangan serta masyarakat lokal yang menerimanya.

Tujuan dari penulisan ini sebenarnya ingin menunjukkan bahwa proses Islamisasi di Nusantara merupakan sebuah peristiwa yang tidak berhenti pada satu 
titik saja, melainkan hampir seluruh wilayah di Nusantara pada abad ke-17 hingga ke-20 merasakan Islamisasi meskipun dengan pola yang berbeda. Di samping itu pula, beberapa kajian mengenai Islamisasi di Nusantara belum menawarkan dan memaparkan Islamisasi di Nusantara secara komprehensif dan holistik, apalagi ketika membaca beberapa kajian yang hanya terfokus pada penekanan geografisnya semata, bukan pada lingkupnya yang lebih luas.

\section{METODE PENELITIAN}

Tulisan ini merupakan tulisan sejarah yang menggunakan metode sejarah. Data kualitatif dimanfaatkan untuk mendeskripsikan, menarasikan, dan menganalisis proses Islamisasi yang terjadi di Semenanjung Laut Sulawesi. Metode sejarah menggunakan empat tahapan utama yakni; heuristik, kritik, interpretasi, dan historiografi untuk menjawab permasalahan yang disampaikan.Metode tersebut yang bersifat analisis-kualitatif menggunakan sumber primer dan sekuder pengumpulan data yang telah dilakukan (Kuntowijoyo, 2003: 94). Sumber utama dalam tulisan ini merupakan arsip, dokumen, dan naskah, serta beberapa buku pendukung untuk menganalisis proses Islamisasi yang berlangsung, khususnya Semenanjung Laut Sulawesi.

Teori mengenai pengaruh Islam di Nusantara sampai sekarang belum selesai. Drewes (1983: 8) dan Snouck Hurgronje (1994: 6), sepakat bahwa Islam berasal dari India yang dibuktikan melalui jejaring niaga dari India hingga ke Nusantara. Di sisi lain, penganut teori Arab (Hasjmy: 1993: 7), Uka Tjandrasasmita (2000:17), dan Naquib Alattas, dalam Azra (2002: 28) membuktikan tidak hanya melalui jejaring perdagangan, tetapi jejaring pemikiran juga berpengaruh yang menghasilkan khazanah dalam literatur Nusantara sebagai worldview keislaman. Pandangan terakhir berasal dari Persia dan Cina yang masing-masing didukung oleh de Graff (1998: 101), Lombard (2008, vol II), melalui warsian tradisi, kultur, hingga keseharian masyarakat muslim Nusantara. Sederhanya, Noourdyn (1972: 10) dan van Leur (1961: 92) berusaha memberikan jalan tengah mengenai aktor, jejaring, hingga lembaga yang membentuk masyarakat muslim yang mencapai puncaknya pada abad ke-19. Oleh karena itu, 
dapat dikatakan bahwa selama proses persebaran Islamisasi di Nusantara terdapat ciri khas dalam prosesnya yakni hubungan awal dari abad ke-7 hingga ke11sebagai fase awal yakni kehadiran, dan hubungan awal dengan para pedagang Muslim di Nusantara. Selanjutnya pertengahan abad ke-11 hingga akhir abad ke16 berdasarkan kekuatan ekonomi-politik dan kebudayaan yang dibuktikan dari terbentuknya kerajaan-kerajaan "berlabel" Islam yang menghubungkan antara aktifitas niaga dan kekuatan politik. Pada abad ke-16 hingga awal abad ke-20 sebagai masa pelembagaan Islam yang secara umum (Ambary, 1998: 50-56; Lombard, 2008, vol I: xix).

Dengan demikian, islamisasi merupakan hal yang tak akan terputus sampai kapan pun melalui proses dan kegiatan penting di dalamnya; berniaga dan berdakwah (Ricklefs, 2008: 3-6). Sejak awal penerimaan sampai pada persebarannya perkembangan tersebut dapat ditelusuri melalui beberapa faktor. Faktor ekonomi dan kondisi masyarakat, serta aktor penyebarnya pun menjadi bagian penting dari islamisasi yang terjadi di Sulawesi Utara. Para aktor memiliki peran masing-masing sesuai dengan "keahliannya" untuk menyebarkan ajaran Islam, apalagi ketika daerah pesisir utara pulau Sulawesi menjadi entrepot para pedagang Muslim yang berusaha menemukan Maluku melalui Laut Sulawesi. Letak posisi yang dalam gambaran para kartografer di masa lalu mengatakan sebagai salah satu tempat strategis untuk menghubungkan daratan Cina dengan Maluku melalui Selat Luzon, Laut Sulawesi menuju Amboina dan Ternate. Dengan demikian, proses Islamisasi yang terjadi harus memiliki batasan dan ruang lingkup untuk memfokuskan penulisan yang dilakukan. Dalam kajian ini dibatasi pada proses Islamisasi di Kawasan Semenanjung Laut Sulawesi melalui jalur perdagangan maritim, terutama ketika para pedagang yang mencari rempahrempah sebagai kawasan strategis penghubung ke daratan Asia, Cina ke daratan Ternate-Tidore. 


\section{PEMBAHASAN}

\section{Awal Kedatangan Islam di Kawasan Laut Sulawesi}

Belum ada angka pasti yang mencatatkan secara pasti mengenai keberadaan ajaran Islam di kawasan Laut Sulawesi. Dari semua sumber yang ditemukan, beberapa di antaranya menghubungkan dengan tiga Kesultanan Islam; Ternate, Makassar, dan Sulu pada abad ke-16 dan ke-17. Pengaruh Islam di masa awal dipengaruhi oleh peran para penguasa dari Kesultanan Ternate. Ternate menjadi penguasa atas wilayah yang ada di sekitarnya, termasuk kawasan Laut Sulawesi. Sebagai penguasa 72 pulau-pulau di antara Ternate dan Laut Sulawesi, Sultan Ternate tidak hanya menaklukkan wilayah melainkan menyebarkan juga pengaruh ajaran Islam. Bagi Kesultanan Ternate peran pedagang ikut membantu persebaran ajaran Islam di kawasan Laut Sulawesi. Wilayah taklukkan dijadikan sebagai vasal dagang oleh Ternate dan secara tidak langsung mereka juga sebagai aktor penyebar ajaran Islam. (Taulu, 1977: 2-4)

Sedangkan bagi Makassar, peran penguasa turut menyebarkan ajaran Islam hingga ke kawasan timur Pulau Sulawesi. Penguasa, yang sekaligus pedagang, berhasil menguasai hampir seluruh daratan Pulau Sulawesi, hingga mampu menanamkan pengaruh politik, ekonomi, hingga agama. Hal ini terlihat dari isi perjanjian Bongaya dimana wilayah kekuasan dan pengaruh Kesultanan Makassar mencapai Buton, Maluku, dan Manado (Mattulada, 2011: 90). Di sisi lain, wilayah kekuasan Makassar dari selatan berawal dari Makassar sampai Manado, van Mandar tot Manado (Mattulada, 2011: 64).

Kesultanan Sulu yang juga tidak lepas proses islamisasi yang berpengaruh di Laut Sulawesi. Berdirinya kedatuan di kepulauan Sangihe tidak lepas dari hubungan yang terjadi dengan Mindanau Selatan. Dalam tradisi lisan juga dikisahkan bahwa ajaran Islam dibawa oleh seorang syarif dari Minagkabau yang melakukan perjalan ke Sulu dan Mindanao sebagai seorang utusan. Pengaruh tokoh tersebut juga sampai ke Pulau Sangihe di Laut Sulawesi pada abad ke-16 (Majul, 1989: 9; Suwondo, 1977/1978: 58). Proses tersebut menunjukkan bahwa terjadi penetration pacifique dalam persebaran ajaran Islam dimana kawasan pesisir laut menjadi wadah perkembangan ajaran Islam yang mengubah tatanan 
masyarakat (al-Hadad, 1957: 49). Perkembangan ini terus berlanjut melalui aktifitas ekonomi para pedagang muslim dimanfaatkan sebagai penyambung antara pedagang rempah-rempah di Nusantara (Lapian, 2008: 72-73).

Gorontalo, yang termasuk dalam kawasan Laut Sulawesi, telah menerima pengaruh ajaran Islam dan tidak terlepas dari pengaruh Ternate pada abad ke-17. Raja Amai menjadi salah satu bukti bahwa pengaruh islamsasi terjadi di Gorontalo. Raja Amai bergelar "sultan" dan menjalankan aturan "Muhammad", bahkan meminta penduduk untuk mendirikan masjid (Tacco, 1935: 26). Selain Gorontalo, di daratan Sangihe dan kawasan kepulauan lainnya pengaruh Islam juga terasa pada abad ke-17. Pengaruh ini dihubungkan dengan aktifitas niaga dari Mindanao dan Ternate (Suwondo, 1977/1978: 59). Pengaruh ini kemudian tidak dapat dipisahkan dari aktifitas niaga yang terjadi di sekitar abad ke-16 hingga abad ke-19 dimana hampir seluruh wilayah merasakan pengaruh Islam (Lapian, 2009: 54).

Pengaruh kekuatan Eropa juga tidak dapat dilepaskan di kawasan Laut Sulawesi. Perebutan pengaruh antara Spanyol dan Belanda di kawasan ini berakibat pada berkurangnya pengaruh islamisasi. Paska terjadinya perjanjian perdamaian antara Spanyol dan Belanda, keduanya memiliki wilayah yang menjadi pusat pemerintahan di kawasan Laut Sulawesi, Spanyol di Zamboanga, dan Belanda di Manado (Lapian, 2009: 69). Kekuatan keduanya berdampak pada perkembangan islamisasi di kawasan Laut Sulawesi. Selain Eropa, pedagang Arab juga menjadi aktor penyebar ajaran Islam di kawasan Laut Sulawesi. Hampir di seluruh kawasan Laut Sulawesi ditemukan pedagang muslim Arab, Bugis, dan Ternate, hingga Jawa (Rompas dan Sigarlaki, 1982/1983: 9). Kedatangan mereka membawa pengaruh terhadap islamisasi di kawasan Laut Sulawesi hingga menjelang abad ke-19.

\section{Jejaring Islamisasi: Antara Hegemoni Politik dan Aktifitas Perdagangan}

Terlepas dari perdebatan mengenai Islamisasi di atas, sekarang, ajaran Islam telah menjadi agama sebagian besar penduduk Indonesia setelah proses panjang yang terjadi di masa-masa sebelumnya. Walaupun teori islamisasi yang 
terjadi di Nusantara lebih menitikberatkan pada Sumatera dan Jawa (Ricklefs, 1990: 20), namun kawasan lain juga perlu diketengahkan di sini. Salah satu kawasan yang perlu dideskirpsikan di sini adalah posisi Maluku, terutama pada abad ke-16, yang dikenal sebagai kawasan "emas hijau" Nusantara.Bagi para pedagang, Maluku adalah kawasan subur penghasil rempah-rempah, pala, lada, bunga pala, dan cengkeh, yang dibutuhkan di pasar internasional.Seiring dengan kebutuhan rempah-rempah di pasar internasional, para pedagang dari berbagai belahan dunia menyebar dan menemukan daerah baru penghasil komoditi, salah satunya Nusantara.Bersamaan dengan proses perdagangan yang berlangsung, proses islamisasi pun terjadi.

Para pedagang telah lama menjalin hubungan dengan Nusantara melalui aktifitas niaga. Hubungan dagang awal antara pedagang Muslim dan Nusantara adalah penggunaan istilah nama "Maluku" dalam berbagai sumber, baik Asia dan Eropa. Dalam Negarakertagama, menuliskan "Maloko", seperti yang dikutip de Graaf, sebagai informasi yang diperoleh dari para petualang ataupun pedagang Arab (de Graaf, 1971: 20). Dengan diperkuat dari asumsi bahwa kata Maluku dipercaya berasal dari kata "Malik" yang diartikan sebagai wilayah yang diisi oleh penguasa-penguasa lokal sebagai raja atau dikenal sebagai "kepulauan raja-raja". Penggunaan istilah Melayu-Islam kemudian memperkuat asumsi hubungan Islam dan wilayah-wilayah di Kepulauan Maluku (Abdurachman, 2008: 213). Pedagang-pedagang Muslim dan juga Melayu berdatangan ke Maluku untuk menjalin jejaring niaga dengan penguasa-pengausa lokal di sana. Tercatat seorang kulano, bernama Kamalu, telah menjalin hubungan dagang dengan para pedagang Jawa, Melayu dan Arab, dan kemudian membawa rempah-rempah Maluku ke pesisir Jawa, Sumatera, dan Malaka (Amal, 2008: 6).

Ketika orang-orang Portugis berhasil menaklukkan Malaka pada tahun 1511, hubungan niaga semakin meluas. Emporium Maluku menjadi tujuan utama para pedagang di seluruh dunia pada awal abad ke-16. Melalui jalur tersebut, Lapian (2008: 56-57) menunjukkan letak strategis Semenanjung Laut Sulawesi dalam jalur pelayaran dan perdagangan rempah-rempah. Ternate, sebagai satu Kesultanan Islam yang berpengaruh di kawasan pulau-pulau Maluku, yang 
mampu menguasai beberapa wilayah kepulauan, hingga ke Semananjung Laut Sulawesi, melalui ekspansi politik.Sultan Ternate mampu membuka dan mempertahankan jalur dan jejaring perdagangan antara Selat Maluku-Laut Sulawesi-Laut Sulu hingga ke daratan Asia Tenggara (Lapian, 2008: 5657).Kawasan-kawasan tersebut menghubungkan Laut Sulawesi, Laut Sulu, dan Maluku pada masa perdagangan rempah-rempah di abad ke-16.

Selain Kesultanan Ternate, Kesultanan Makassar juga memiliki pengaruh dan peran di kawasan Semenanjung Laut Sulawesi. Peran Makassar dalam perdagangan dan persebaran Islam terlihat di masa Sultan Alauddin yang menerapkan kebijakan ekonomi terbuka. Bagi Sultan Alauddin, tidak ada wilayah yang dapat dikuasai oleh satu kelompok atau bangsa tertentu, melainkan semua wilayah merpakan kawasan terbuka dan bebas bagi siapa saja, karena semua itu pemberian Tuhan (Mattulada, 2011: 61). Berdasarkan hal tersebut, Makassar kemudian menjalin hubungan dengan siapapun tanpa mementingkan bangsa, etnis, dan agamanya, yang berdampak pada kejayaan Makassar di kawasan Semenajung Laut Sulawesi.

Tidak hanya sampai di situ, Makassar juga memperluas wilayahnya sampai ke kawasan Timur lainnya. Dalam berbagai literatur disebutkan bahwa wilayah kekuasaan Kesultanan Makassar sampai ke Nusa Tenggara dan Kepulauan Kei di Maluku. Namun kondisi tersebut membuat Sultan Makassar harus menghadapi peran Ternate untuk memperkuat posisinya di daratan tersebut. De Clercq (1890: 54), dan Valentijn (1724, vol I: 208) menuliskan bahwa Baabullah menawarkan kepada Sultan Makassar untuk bekerjasama agar peran politik dan agama mereka mampu membendung Portugis, namun hal tersebut tidak terjadi.

Selain Kesultanan Makassar, peran Kesultanan Sulu juga berpengaruh di Semenanjung Laut Sulawesi. Peran para pedagang dari Sulu membawa dampak positif dengan memperkenalkan Islam dari kawasan utara. Kesultanan Sulu yang berpusat di Jolo telah mengirimkan armada lautnya ke Sangihe-Talaud pada awal abad ke-17. Ketika itu seorang Sultan Sulu bernama Pangiran Buddiman, mendaulat dirinya sebagai penguasa Sulu, Tawi-Tawi, Manguindanao, 
Zamboanga, dan Mindanao. Dia mendaulat dirinya karena telah berhasil menggantikan Maharaja Upo sebagai penguasa Sulu dan mengeluarkan titah bahwa syarat kedaulatannya adalah menguasai dan menduduki Maluku dan wilayah bawahannya termasuk Sangihe-Talaud, dan Manado (Hayase dkk, 1999: 9-11). Pengakuan kedaulatan tersebut kemudian ditolak oleh Spanyol atas Pangiran Buddiman, dan menunjuk Don Manrique de Lara dan Don Diego Salcedo sebagai gebernur Sulu (Permanent Arbitration, 1925:10). Meskipun demikian, Semenanjung Laut Sulawesi dan pulau-pulau kecil lainnya antara Sulu dan Maluku dijadikan sebagai jembatan alami menuju Nusantara.

Jalur Islamisasi di Semenanjung Laut Sulawesi pada pertengahan abad ke17 memiliki kondisi yang berbeda dengan Jawa dan Sumatera, sehingga tidak berdampak signifikan. Penerus Sultan Pangiran Buddiman, Sultan Shah Tangah dan Sultan Bungsu, hanya memerankan peran kecil dalam mengirim pedagang ke Maluku melalui Pelabuhan Tahuna, Sangihe. Penguasaan Belanda, Great Britain (Inggris) dan Spanyol menghalangi Islamisasi di sana melalu perjanjian dengan Sultan Sulu termasuk dengan Pangiran Bakhtiar. Hanya Sangihe dan Talaud yang merasakan Islamisasi dari kawasan Kesultanan Sulu yakni dari pedagang dan keturunan dari Syarif Awliya karim al-Makhdum (Saleeby, 1908: 158). Di Sangihe, Kedatuan Kendahe telah mengenal ajaran Islam yang dibawa oleh tiga Imam bernama Mahdum, Mas'ud, dan Hadung. Hal ini mengindikasikan bahwa Mahdum yang dikenal adalah seorang Syarif Awliya yang bernama Karim alMakhdum dari daratan Sulu, Jolo (Suwondo, 1977/1978: 59). Oleh karena itu, Islamisasi di Kepulauan Sangihe dapat disebut sebagai bukti bahwa ajaran Islam pernah mengisi skep dan space di Kepuluan Sangihe melalui pelabuhan Tahuna. Sampai sekarang ajaran Islam masih bertahan di Kepulauan Sangihe dengan ajaran lokal Islam Masade’.

Selain peninggalan melalui pengaruh pemikiran, pengaruh kebudayaan dan identitas juga terlihat dalam suskesnya islamisasi. Penggunaan istilah Melayu dan Arab juga digunakan sebagai identitas kekuatan politik di sekitar Semenanjung Laut Sulawesi. Istilah penggunaan, datu, raja, negerij, hingga syahbandar dipakai pada beberapa kerajaan di kawasan Semenanjung Laut 
Sulawesi. Di samping itu, ditemukan seorang raja yang menggunakan gelar Arab sebagai penguasa. Dia bernama Raja Syam Syah Alam dengan gelar Syarif Maulana yang berkuasa di Kerajaan Kendahe pada pertengahan abad ke-17. Selanjutnya, istilah “kedatuan' juga digunakan untuk merujuk pada beberapa kerajaan yang berdiri di sekitar Semenanjung Laut Sulawesi seperti Kendahe Manganitu, Tabukan, Tahuna, dan Siau merujuk pada penggunaan di daratan semenanjung Melayu. Melihat dari penjelasan Pigafetta dan gelar yang tersemat pada penguasa Kendahe, Syarif Maulana, maka Islam di Kesultanan Sulu, Jolo, dan di Kepulauan Sangihe memiliki hubungan.Meskipun tidak ada tahun pasti mengenai dari siapa dan kapan Syam Syah Alam mendapatkan gelar sebagai Syarif Maulana, kita bisa melihat dari silsilah yang terdapat pada Kesultanan Manguindanao yang dipipin oleh Sultan Syarif Muhammad Kabungsuan.Ini berarti bahwa bisa saja dan memungkinkan bahwa Datu Syam Syah Alam merupakan raja bawahan dari Sultan Syarif Maulana Kabungsuan (Saleeby, 1908: 161).

Daratan Minahasa yang menganut kepercayaan polytheisme telah terlebih dahulu menjalin hubungan dengan Spanyol sehingga penduduk Minahasa telah memeluk agama Katolik (Saleeby, 1908: 172). Karena adanya pengkhianatan dari Spanyol yang merusak perjanjian dengan rakyat Minahasa maka, orang-orang Spanyol diusir dari tanah Minahasa di bawah pimpinan Bortolemeu de Souse (1651). Para pemimpin Minahasa: Supit, Paat, dan Lontak dengan segera meminta bantuan kepada VOC agar Spanyol diusir dari Minahasa. Akhirnya Belanda mendirikan kembali loji dagang di Manado pada tahun 1657 di bawah pemerintahan Gubernur Sigimon Cos dan Spanyol berhasil diusir dari Minahasa pada tahun 1660 (Graafland, 1981: 9-10).

Pengaruh Islam pun di tanah Minahasa terasa ketika Ternate berhasil memasukkannya sebagai daerah istimewa.Rupanya hal ini tidak terlepas dari pengaruh VOC, Belanda, yang melakukan pekebaran Injil sebelum pengaruh Kesultanan Ternate menguat di Minahasa. H.B. Palar memberikan penjelasan mengenai pekabaran Injil tersebut berdasarkan perjanjian yang terjadi antara Ternate-VOC menyepakati bahwa daerah yang berada di bawah pengaruh Ternate 
membuka diri bagi agama Islam, kecuali daerah pedalaman Minahasa, highlanders atau alfur (Palar, 2009: 135-136). Sultan Ternate mengakui bahwa daratan di Laut Sulawesi berada dalam perlindungannya, vassal, dan berhak mendapatkan keamanan dan hak beragama tanpa adanya paksaan untuk memeluk agama Sultan (Islam) (Lapian, 2009: 70; Taulu, 1977: 5). Dari pengakuan Sultan Ternate ini menunjukkan bahwa dia menerima adanya pluralisme agama tanpa memaksa rakyat dan menggunakan hak preogatifnya untuk menjadikan Islam sebagai agama resmi di Ternate seperti yang terjadi di beberapa wilayah Kesultanan Nusantara.

Pengaruh Islam tidak hanya berhenti di Minahasa saja, namun dalam catatan ditemukan datamengenai Islam di Minahasa yang tidak berkembang, namun ada sebuah wilayah di pesisir selatan Minahasa yang sebagian besar penduduknya telah memeluk agama Islam. Di Belang, peran pedagang Ternate bernama Syarif Abdul Wahid masuk dan menetap (Taulu, 1977: 8). Selain di Belang, Bolaang-Mongondow juga menerima pengaruh pedagang Ternate bernama Sayrif Aluwi atau Alawi dan menikahi adik Raja Cornelis Manoppo (Taulu, 1977: 7). Dan di daratan Minahasa terlihat dari peran bandar Manado dimana ditemukan nisan orang Arab, bernama Al Said Zen bin Alwi Zenlads dan Al Said Zen bin Zenaldus, yang diduga sebagai pedagang sejak abad ke-17. (Rompas dan Sigarlaki, 1982/1983: 9) Dengan demikian, jejak islamisasi di daratan Laut Sulawesi dapat ditarik pada satu konteks yakni aktifitas niaga.

Di kawasan Laut Sulawesi, daratan Bolaang Mongondow, ajaran Islam pertama kali diperkenalkan pada tahun 1653 di bawah pemerintahan Raja Laloda Mokaagow (Schefold, 1995: 26). Dia menjalin hubungan persahabatan dengan Sultan Ternate dengan tujuan mendapatkan keamanan dan mengakui Kesultanan Ternate sebagai penguasa tertinggi di Sulawesi Utara berdasarkan perjanjian Ternate dan VOC. Bolaang Mongondow menjadi vassal Ternate yang memberikan upeti kepada Ternate, seperti yang terjadi di Minahasa. Namun Islamisasi yang terjadi hanya sebatas di sekitar istana kerajaan dan kerabat raja.Rakyatnya masih menganut kepercayaan leluhur, animisme dan dinamisme sebagai kepercayaan utama hingga VOC mengambil alih daerah Bolaang 
Mongondow dari Ternate dan berhasil menyebarkan ajaran Kristen (Suwondo, 1977/1978: 58). Di sini kemudian terlihat kemunculan Islam di kawasan tersebut adalah bagian dari integrasi dan akumulasi ekonomi yang menjadi kekuatan politik (de Graaf dan Pigeaud, 1985: 26-27)

Pada masa selanjutnya, Islam kembali berkembang melalui daerah Lipung yang merupakan daerah Kekuasaan Jacobus Manuel Manoppo. Di Lipung terdapat seorang budak belian bernama Imam Tueko dan pengaruh dari beberapa Ulama dari Mekkah pada akhir abad ke-19, dan bahkan pedagang Bugis dan Makassar dari daerah Sulawesi Selatan. Oleh karena itu, Islam di daerah Bolaang Mongondow, khususnya di daerah Kotamobagu diterima oleh masyarakat dan menjadi agama dengan mayoritas penganut (Sigarlaki, 1977: 187). Dengan dijadikannya Islam sebagai agama resmi dikerajaan, maka raja Jocobus Manuel Manoppo mengintruksikan untuk mendirikan sebuah masjid dan pesantren dengan tujuan memperkenalkan ajaran Islam.

\section{Islamisasi di Semenanjung Laut Sulawesi Abad XIX}

Sejarah islamisasi yang tercatat di Semenanjung Laut Sulawesi masih kurang ditemui, sehingga perlu kejelian dalam membaca setiap data dan sumber yang ada. Bahasan ini memberikan deskripsi dan analisis singkat mengenai wilayah yang mengalami proses islamisasi, termasuk kawasan Laut Sulawesi. Kawasan-kawasan tersebut di masa sekarang ini menjadi kantung-kantung umat Islam di kawasan Laut Sulawesi yang mempertahankan eksistensi peradaban dan kebudayaan Islam.

Ada beberapa wilayah di Semenanjug Laut Sulawesi yang pernah merasakan pengaruh Islamisasi di antaranya; Selat Makassar, kawasan pesisir Selatan Laut Sulawesi, hingga beberapa pulau-pulau kecil di sekitarnya. Dalam catatan yang ditemukan, perkembangan agama di kawasan tersebut cukup dinamis dimana terdapat pengaruh agama sebagai arus utama; Islam, Katolik, dan Protestan. Data ini menarasikan mengenai periodisasi yang berbeda dan dipisahkan secara kronoloogis. Pertama awal perjumpaan Islam dengan wilayahwilayah di Semenanjung Laut Sulawesi sejak abad ke-16 hingga abad ke-19; 
kedua, perjumpaan Katolik dengan wilayah-wilayah di Semenanjung Laut Sulawesi sejak abad ke-16 hingga abad ke-17; ketiga, perjumpaan Protestan dengan wilayah-wilayah lainnya di Semenanjung Laut Sulawesi sejak abad ke-17 hingga abad ke-20. Tiga periodisasi ini melihat pada kawasan utama yang merasakan ketiga arus utama tersebut yakni Residentie Ternate dan Residentie Manado.

Mengenai persebaran keagamaan di Semenanjung Laut Sulawesi, Lapian (1984: 28-43) menuliskan bahwa di wilayah tersebut hegemoni ekonomi dan politik mempengaruhi persebaran keagamaan di sekitar abad ke-16 dan ke-17. Secara eksplisit Lapian (1984: 34-40) menuliskan peningkatan aktifitas pelayaran dan perdagangan mendorong persebaran ajaran keagamaan. Persebaran agama semakin signifikan ketika pelayaran dan perdagangan ikut meningkat akibat faktor ekonomi, salah satu kawasan yang terkena dampak dari peningkatan pelayaran dan perdagangan serta tersebarnya ajaran Islam adalah wilayah pesisir Manado.

Manado merupakan salah satu kawasan yang cukup unik dalam persebaran ajaran keagamaan di abad ke-16 hingga abad ke-19. Data mengenai kesuksesan kristenisasi di kawasan ini cukup banyak disinggung oleh para penulis, terutama penulis Belanda. Moelsbergen (1928: 8-9) mencatatkan bahwa misi Katolik terlihat sejak abad ke-16, ketika Spanyol melanjutkan perjalanan dari Filipina menuju Maluku, terutama pada tahun 1564. Selanjutnya misi Protestan terjadi ketika VOC menjalin hubungan dagang dengan Minahasa. Tepatnya pada tahun 1677, VOC sudah mengirimkan misionaris di Manado sebagai awal dari proses hubungan keagamaan (Kruger, 1966: 105-106). Kemudian ajaran Islam sudah terlihat sejak abad ke-17 dimana terbukti sebuah batu nisan dua orang pedagang Muslim bernama Al Said Zen bin Alwi Zenald dan Al Zaid Zen bin Zenaldus yang beranotasi tahun 1685 dan 1689 (Sigarlaki dan Rompas, 1982/1983: 9). Sedangkan pada masa selanjutnya, kehadiran agama-agama lainnya disebabkan oleh migrasi dan diaspora masyarakat di masa modern yang tujuannya sebagai pekerja semata (Sigarlaki, 1977: 187).

Dampak panjang dari persebaran ajaran Islam di kawasan Laut Sulawesi yakni masyarakat yang heterogen. Di Minahasa dan Manado tercatat bahwa 
penduduk mencapai sekitar 63.704 jiwa pada tahun 1821. Distribusi penduduk ini lebih terdiri atas para pendatang dari Cina, Arab, Bugis, dan Ternate (Makkelo, 2010: 29). Tidak jauh berbeda, di Gorontalo kekuatan pedagang muslim, Bugis dan Arab berperan dalam persebaran pemeluk ajaran Islam. Pada tahun 1866, penduduk Gorontalo mencapai 66.146 jiwa yang cenderung menetap berdasarkan identitas etnisnya. Selain itu, faktor lain yang membuat penduduk Gorontalo heterogen adalah pengelompokan penduduk yang tidak banyak beraktifitas dengan orang Eropa (Rosemberg, 1856: 15; Riedel, 1869: 64).

Menariknya, keberadaan umat Islam pada perkembangannya, terutama pada abad ke-19, dilaporkan berasal dari para tenaga ahli yang didatangkan oleh Belanda ke kawasan Laut Sulawesi. Tukang-tukang didatangkan oleh Belanda untuk membangun benteng dan laji dagang (Taulu, 1977: 9; Manus, 1980/1981: 44). Sedangkan di beberapa kawasan lain, pedagang muslim berperan sebagai perantara untuk pedagang pribumi dan Eropa. Hal ini terjadi karena adanya kebijakan Belanda menjadikan kawasan Laut Sulawesi sebagai daerah koloni untuk memenuhi kebutuhan komoditas. Di sisi lain, Belanda berusaha memperkuat dominasi ekonomi-politiknya agar para pedagang tidak leluasa (Juwono dan Hutagalung, 2005: 341).

Akibatnya muncul kantung-kantung pemukiman Islam di daerah pesisir Laut Sulawesi. Di Manado dan Minahasa kawasan pesisir pelabuhan Manado ${ }^{1}$ dan Kema $^{2}$ menjadi kawasan yang berpenduduk mayoritas Muslim. Walau ajaran lslam tidak diterima secara besar-besaran seperti yang terjadi di Sumatera, Jawa, Makassar, dan Maluku, namun terdapat proses yang unik dan ciri khas Islamisasi di kawasan ini. Salah satu bukti yang masih bertahan sampai sekarang adalah bertahannya kampung Arab di Manado, Kampung Islam Jawa di Tondano, Kampung Arab dan Bugis di Gorontalo, hingga perkampungan Islam di Kepulauan Sangihe dapat dikatakan sebagai salah satu kesuksekan dari

\footnotetext{
${ }^{1}$ Hal ini dapat ditemukan dari laporan perjalanan Graafland mengenai perkampungan Islam yang terletak di hulu Sungai Tondano dan Teluk Manado. Graafland menyebutnya sebagai "Kampung Islam”.

${ }^{2}$ Kema disebutkan sebagai salah satu pelabuhan yang menjadi pintu masuk bagi para exile dari berbagai wilayah di Nusantara pada abad ke-19. Beberapa tokoh Muslim seperti Pangeran Diponegoro, Kyai Modjo, Imam Bonjol, hingga Said Abdullah Assagaf.
} 
penyebaran Islam di Laut Sulawesi (Schefold, 1995: 75; Lamanginda, 2003: 132133; Hasanuddin, 2014: 90-91; Djakaria, 2002: 21).

Eksitensi masyarakat Muslim di kawasan Laut Sulawesi banyak terlibat dalam aktifitas ekonomi-politik pemerintah kolonial. Di Manado, pecahnya pemberontakan yang dilakukan oleh seorang Syarif dari Buol menunjukkan bahwa peran umat Islam perlu diperhitungkan pada abad ke-19 (Juwono dan Hutagalung, 2005: 341). Di Tondano, para buangan kolonial paska Perang Jawa, berdampak pada kehidupan umat Islam di Minahasa. Mayoritas di antara mereka adalah para exiler melakukan pernikahan dengan wanita setempat (Sandiah, 2002: 28). Hal tersebut berdampak positif pada perkembangan Islam di kawasan Laut Sulawesi. Sejarah mencatatkan bahwa perkembangan ajaran Islam di kawasan Laut Sulawesi berdampak signifikan. Pada akhir abad ke-19, kawasan ini mampu menjadi bagian yang menghubungkan masyarakat Muslim di Nusantara. Bukti yang konkret yang dapat ditemukan dari jejaring proses islamisasi tersebut adalah hubungan keilmuan yang mengintegrasikan antara kawasan Laut Sulawwsi dan pusat-pusat keilmuan di Jawa dan Sumatera (Bizawie, 2016: 242-243).

\section{PENUTUP}

Proses awal Islamisasi di kawasan Laut Sulawesi tidak lepas oleh faktor ekonomi-politik yang terjadi sejak abad ke-17. Interaksi perdagangan kolonial menjadi faktor utama persentuhan Islam dan penduduk pribumi di kawasan Laut Sulawesi. Tidak hanya sampai di situ, kekuatan Islam, melalui Kesultanan Islam; Makassar, Ternate, dan Sulu, ikut terlibat dalam proses persebaran Islam. Maluku sebagai tujuan utama kemudian membuat kawasan Laut Sulawesi menjadi daerah entrepot. Jaringan perdagangan yang terbentuk, para pedagang, hingga hubungan politik mengintegrasikan proses islamisasi pada abad ke-19. Puncaknya ketika penduduk pribumi menjalin hubungan niaga, dan lambat laun menerima kedatangan mereka sebagai pedagang, dan secara tidak langsung menyebarikan ajaran Islam. Di kawasan Laut Sulawesi, sebagai penduduk pribumi secara terbuka menerima sebuah peradaban dan pengaruh baru, sebelum masuknya 
pengaruh Eropa. Penerimaan ini dikarenakan adanya unsur-unsur penting: ekonomi dan politik yang bertujuan berdagang.

Jejaring perdagangan di kawasan Laut Sulawesi sebagai ruang terbuka membawa ajaran Islam semakin tersebar luas. Kehadiran para exile dari Sumatera dan Jawa memperkuat keberadaan Islam di daratan Laut Sulawesi. Mereka yang dibuang oleh pemerintah kolonial memiliki pengaruh kuat dalam bidang keagamaan di antaranya; Pangeran Diponegoro dan Kyai Modjo. Di sisi lain, pedagang Arab, Bugis, dan Ternate juga mempercepat proses penyebaran ajaran Islam di kawasan tersebut dimana mereka membentuk jejaring niaga dan menyebarkan ajaran Islam dengan cara soft aprroachment pada bidang perdagangan. 


\section{DAFTAR PUSTAKA}

Abdurachman, Paramita R., 2008. Bunga Angin Portugis di Nusantara: Jejakjejak Kebudayaan Portugis di Indonesia, Jakarta: LIPI Press dan Yayasan Obor Indonesia.

Amal, M. Adnan, 2007. Kepulauan Rempah-Rempah: Perjalanan Sejarah Maluku Utara 1250-1950, Jakarta: Kepustakaan Populer Gramedia.

Ambary, Hasan Mu'arif, 1998.Menemukan Peradaban: Jejak Arkeologis dan Historis Islam Indonesia, Jakarta: Logos Wacana Ilmu.

Ali, K., 1976. Isamer Itihash, Dhaka: Ali Publication.

Bizawie, Zainul Milal, 2016. Masterpiece Islam Nusantara, Sanad dan Jejaring Ulama-Santri (1830-1945), Jakarta: Pustaka Compass.

Berg, L. W. C. van den, 2010. Orang Arab di Nusantara, terj. Rahayu Hidayat, Jakarta: Komunitas Bambu.

Carey, Peter,2011. Kuasa Ramalan: Pangeran Diponegoro dan Akhir Tatanan Lama di Jawa (1785-1855), Jakarta: Kepustakaan Populer Gramedia.

Clercq, F. S. A. De, 1890. Bidjragen tot de kennis der Residentie Ternate, Leiden: E. J. Brill.

Djakaria, Salmin, 2002. "Sekelumit Tentang Kampung Jawa Tondano" dalam Niyaku Tondano, Maulud Tumenggung Zis dan Orang Jaton, Manado: BKSNT Manado bekerjasama dengan Laboratorium FISIP UNSRAT Manado.

Drewes, G. W. J. 1983. "New Light on the Coming of Islam in Indonesia", dalam Reading on Islam in Southeast Asia, Singapore: Institute of Southeast Asia Studies (ISEAS).

Graaf, H. J. De, 1977. De Geschidenis van Ambon en de Zuid Molukken, Franeker: Wener BV.

--, dan Th. G. Pigeaud, 1974. "De Eerste Moslime Vorstendommen op Java. Studien over de Staatkundige Geschidenis van de 15de en 16de EEUW", Verhandelingen van het Koninklijk Instituuut voor Taal-, Landen Volkenkunde (VKI) No. 69. 's-Gravenhage: Martinus Nijhoff.

, dkk, 1998. Cina Muslim di Jawa Abad XV dan XVI: Antara Historis dan Mitos, Yogyakarta: Tiara Wacana.

al-Haddad, Syed Alwi bin Tahir, 1975. Sejarah Islam di Timur Jauh, Terj. Dziya Shahab, Jakarta: al-Maktabah addaimi.

Hasanuddin, 2014. Pelayaran dan Perniagaan Gorontalo Abad ke-18 dan 19, Yogyakarta: Kepel Press.

Hayase,Shinzo, Domingo M. Non dan Alex J. Ulaen, 1999. Silsilah/Tarsilas (Genealogis) and Historical Narratives in Saranggani Bay and Davao 
Gulf, South Mindanao, Philippnes, and Sangihe-Talaud Islands, North Sulawesi, Indonesia, Japan: CSAS Kyoto University.

Hurgronje, Snouck, 1994. "Arti Agama Islam Bagi Penganutnya di Hindia Belanda, dalam Kumpulan Karangan Snouck Hurgronje, jil. VII, Jakarta: INIS.

Hasymy, A. 1993. Sejarah Masuk dan Berkembangnya Islam di Indonesia, Bandung: Alma'arif.

Jhons, A. H.,1995. "Sufism in Southeast Asean", dalam Journal of Southeast Asian Studies, Vol. 26, No. 1, Perpsective on Southeast Asean Studies, Singapore: Cambridge University Press. hal. 174-175

Juwono, Harto, dan Yosephine Hutagalung, 2005. Limo Lo Pohalaa: Sejarah Kerajaan Gorontalo, Yogyakarta: Ombak.

Karim, M. Abdul, 2014. Sejarah Pemikiran dan Peradaban Islam, cetakan ke-V, Yogykarta: Bagaskara.

Lamanginda, Yoran, 2002. "Masyarakat Keturunan Arab di Manado" dalam Esagenang, vol. 1, no. 1, Februari 2003, Manado: BKSNT Manado, hlm. 123-142.

Lapian, Adrian B., 2008.Pelayaran dan Perniagaan Nusantara Abad ke-16 dan 17,Jakarta: Komunitas Bambu.

Leur, J. C. van,1961. Indonesia Trade and Society, The Hague dan Bandung: Matinus Nijhoff.

Lombard, Denys, 2008. Nusa Jawa Silang Budaya: Batas-Batas Pembaratan, vol I, Jakarta: PT. Gramedia Pustaka.

Majul, Cesar A., 1989. Dinamika Islam di Filipina, Jakarta: LP3ES.

Makkelo, Ilham Daeng, 2010. Kota Seribu Gereja, Yogyakarta: Ombak.

Manus, Laurens. Th.,1978. Sejarah Kebangkitan Nasional Daerah Sulawesi Utara, Manado: P3KD Depdikbud.

Manus, Laurens. Th. dkk., 1980/1981. Sejarah Pendidikan Daerah Sulawesi Utara, Manado: Pusat Penelitian Sejarah dan Budaya Depdikbud.

Mattulada, 2011.Menyusuri Jejak Kehadiran Makassar dalam Sejarah, Yogyakarta: Ombak.

Noourdyn, J., 1972. Islamisasi Makassar, Jakarta: Bharata, 1972.

Palar, H. B., 2009. Wajah Lama Minahasa, Jakarta: Penerbit Yayasan Gibbon Indonesia.

Ricklefs, M. C., 2008. Sejarah Indonesia Modern 1200-2008, Jakarta; Serambi.

Saleeby, Najeeb M., 1908. The History of Sulu, Manila: Beureau of Printing. 
Schefold, Reimar(ed.), 1995.Minahasa Past and Present: Tradition and Transition in an outer Island Region of Indonesia, Leiden: Research School CNWS.

Sewang, Ahmad M., 2005. Islamisasi Kerajaan Gowa: Abad XVI Sampai Abad VII, Jakarta: Yayasan Obor Indonesia.

Sigarlaki, A.(eds.), 1977, Sejarah Daerah Sulawesi Utara, Manado: P3KD Sulawesi Utara.

Rompas, A. E., dan A. Sigarlaki, 1982/1983. Sejarah Masuknya Islam di Kota Manado, Manado: Univeristas Sam Ratulangi.

Rosemberg, C. B. H. von, 1865. Reistogen in de Afdeeling Gorontalo, gedaan op last der Nederlandsch Indische regering, Amsterdam: Muller; Riedel, J. G. F. 1869. "Het Landschappen Holontalo, Limoeto, Bone, Boalemo, en Kattinggola of Andagile: geographische, staatistiche, historiche en etnographische aanteekeningen" dalam Tidjdschrift voor Indische TaalLand- en Volkenkunde (TBG), vol. XIX.

Sis, M. Tumenggung, 2002, "Etnik Minoritas Islam Minahasa di Daerah Minahasa", dalam Nasrun Sandiah dan Alex J. Ulaen (ed.), Niyaku Tondano, BKSNT Manado.

Suwondo, Bambang, 1977/1978. Sejarah Daerah Sulawesi Utara, Jakarta: P3K Depdikbud.

Tacco, Richard, 1935. Het Volk van Gorontalo: Historisch, traditioneel, maatschappelijk, cultureel, social karakteristiek en ecnomisch, Gorontalo: Yo Un Ann \& Co.

Taulu., H. M., 1977. Sejarah Ringkas Masuknya Islam di Sulawesi Utara, Manado, Yayasan Manguni Render

Tignor, L., 1972. The American Historical Review, vol. 77, No. 1, Oxford University Press on behalf of The American Historical Association.

Tjandrasasmita, Uka, 2000. Pertumbuhan dan Perkembangan Kota-kota Muslim di Indonesia dari Abad XIII sampai SVIII M., Kudus: Menara Kudus.

Ulaen, Alex J. 2016. Nusa Utara: Dari Lintasan Niaga ke Daerah Perbatasan, Yogykarta: Ombak

Valentijn, Francois, 1724. Oud en Nieuw Oost-Indien veravattend een naaukerige en Uuitvoerige verhandeling van Nederland Mogentheyd en die Gewesten Beneveens, vol. I, Dordecht \& Amsterdam: Joannes van Braam \& Gerrard Onder de Linden.

Warren, Jim, 1979. "The Sulu Zone" Commerce and Evolution of a Multi-Ethnic Polity, 1768-1898”, dalam Archipel, Jakarta-Paris. 